\title{
Impact of deep convection in the tropical tropopause layer in West Africa: in-situ observations and mesoscale modelling
}

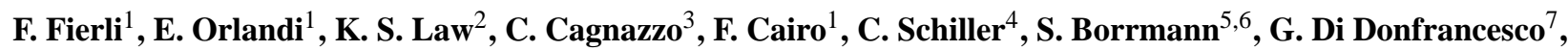 \\ F. Ravegnani ${ }^{1}$, and C. M. Volk ${ }^{8}$ \\ ${ }^{1}$ Institute for Atmospheric Sciences and Climate, ISAC-CNR, Italy \\ ${ }^{2}$ UPMC Univ. Paris 06; Univ. Versailles St-Quentin; CNRS/INSU, UMR 8190, LATMOS-IPSL, Paris, France \\ ${ }^{3} \mathrm{CMCC}$, Bologna, Italy \\ ${ }^{4}$ Forschungzentrum Juelich, Juelich, Germany \\ ${ }^{5}$ Max Planck Institute for Chemistry, Particle Chemistry Department, Mainz, Germany \\ ${ }^{6}$ Institute for Atmospheric Physics, Johannes Gutenberg University, Mainz, Germany \\ ${ }^{7}$ ENEA, UTMEA-TER, Rome, Italy \\ ${ }^{8}$ Department of Physics, University of Wuppertal, Wuppertal, Germany
}

Received: 28 December 2009 - Published in Atmos. Chem. Phys. Discuss.: 18 February 2010

Revised: 28 November 2010 - Accepted: 30 November 2010 - Published: 11 January 2011

\begin{abstract}
We present the analysis of the impact of convection on the composition of the tropical tropopause layer region (TTL) in West-Africa during the AMMA-SCOUT campaign. Geophysica M55 aircraft observations of water vapor, ozone, aerosol and $\mathrm{CO}_{2}$ during August 2006 show perturbed values at altitudes ranging from $14 \mathrm{~km}$ to $17 \mathrm{~km}$ (above the main convective outflow) and satellite data indicates that air detrainment is likely to have originated from convective cloud east of the flights. Simulations of the BOLAM mesoscale model, nudged with infrared radiance temperatures, are used to estimate the convective impact in the upper troposphere and to assess the fraction of air processed by convection. The analysis shows that BOLAM correctly reproduces the location and the vertical structure of convective outflow. Model-aided analysis indicates that convection can influence the composition of the upper troposphere above the level of main outflow for an event of deep convection close to the observation site. Model analysis also shows that deep convection occurring in the entire Sahelian transect (up to $2000 \mathrm{~km} \mathrm{E}$ of the measurement area) has a non negligible role in determining TTL composition.
\end{abstract}

Correspondence to: F. Fierli

(f.fierli@isac.cnr.it)

\section{Introduction}

The role of deep convection and of large scale transport in determining the composition of the upper troposphere region is still a question of debate. The height where convection dominates is an important question to answer, since it impacts substantially the chemical composition, hence the radiative equilibrium in the tropical tropopause layer (TTL) (Fueglistaler et al., 2009; Corti et al., 2006).

Several studies (see for instance Folkins and Martin (2005); Fueglistaler and Fu (2006)) pointed out that TTL composition is controlled by slow upwelling driven by radiation, while convection determines the composition up to the lower boundary of the TTL $(350 \mathrm{~K}$ in potential temperature coordinates) through fast vertical transport. The determination of the height of convective clouds and their subsequent impact on TTL composition is difficult to achieve from satellite measurements due to the low sensitivity of observed parameters from, for example METEOSAT, at the tropical tropopause due to the limited vertical resolution of satelliteborne profilers. The information on the height where deep convection outflow occurs and modifies water vapour and trace gas distributions can be derived from in-situ observations that offer an adequate vertical resolution. Several observational analyses based on in-situ aircraft data show that deep convection can impact up to the tropical tropopause (Dessler, 2002). Locally, convection can overshoot up to the lower stratosphere influencing directly the water budget above the tropopause as observed during the convective season in Brazil (Chaboureau et al., 2007), above the Hector

Published by Copernicus Publications on behalf of the European Geosciences Union. 
convective system in northern Australia (Corti et al., 2008), and in West Africa (Khaykin et al., 2009).

The role of convection in West Africa is still poorly known; local convection superimposes its signature on the large scale circulation that is characterized by an easterly jet that transports air in the UT-LS from the Indian Ocean where deep convection in monsoon area occurs (Barret et al., 2008). A large field campaign in the framework of AMMA (African Monsoon Multidisciplinary Analyses, Redelsperger et al. (2006)) was devoted to the study of the dynamics and chemical composition of atmosphere in West Africa (Reeves et al., 2010) and, in August 2006, a specific observational activity focused on the TTL based on the M55-Geophysica observations took place (Cairo et al., 2010). The meteorological situation and phases of convective activity during 2006 wet season have been described in detail by Janicot et al. (2008).

Ancellet et al. (2009) analysed the role of local convection on tropospheric aircraft observations and concluded that convective transport played a role in governing concentrations of ozone and other chemical tracers during the wet season up to $250 \mathrm{hPa}$ in August 2006. Signatures of convection can be identified as deviations of tracer concentrations from mean profile due to rapid vertical transport from the planetary boundary layer; several typologies of air masses have been identified with highly variable values of $\mathrm{CO}$ and $\mathrm{O}_{3}$ mixing ratios depending on the emissions in the region where convection occurred and subsequent chemical processing in the upper troposphere. West Africa is characterized by the presence of potentially important and poorly known sources of aerosol and ozone precursors. Large latitudinal variability of nitrogen oxides emissions in West Africa during the wet season was observed during AMMA and is reported by Stewart et al. (2008); $\mathrm{NO}_{\mathrm{x}}$ levels in the Sahelian area are high leading to higher ozone mixing ratios (Saunois et al., 2009) while ozone precursors from biomass burning in the southern hemispheric African continent can be transported by deep convection in the upper troposphere up to $10^{\circ} \mathrm{N}$ (Mari et al., 2008; Real et al., 2010).

A companion paper (Law et al. (2010) hereafter Law2010) presents the analysis of transport based on European Center for Medium Range Weather Forecast (ECMWF) data showing that large scale transport plays a pivotal role in determining average vertical distribution of trace species in the UTLS over West Africa while local convection has a dominant impact up to the lower boundary of the TTL (on average $180 \mathrm{hPa}$ ); air masses are lifted from the troposphere in the Indian Ocean and warm pool region and then advected westward by the tropical easterly jet. Schiller et al. (2009) analysed satellite observations coupled to a Lagrangian transport model showing that average values of water vapour in the UTLS appear to be controlled by large-scale transport. Nevertheless, the analysis of aircraft and balloon-borne observations indicates that local convection, i.e. convection formed in the Sahelian region extending from Sudan to West Africa between $10^{\circ} \mathrm{N}$ and $15^{\circ} \mathrm{N}$, are likely to be superimposed on this zonal transport and directly influence the composition in the tropical upper troposphere above $200 \mathrm{hPa}$ over West Africa and downwind. Law2010 gives some indications of large scale organised uplift estimated from trajectories based on large scale analyses, that likely underestimates the effects of local convection. Here we use a mesoscale model to investigate the role of convective uplift on trace gas and aerosol concentrations over West Africa during August 2006.

The analysis is restricted to flights where there was potentially a strong influence from local convection and data collected on these specific flights are used to examine whether signatures of local deep convection can be seen in the chemical data. Moreover, the mesoscale simulations are used to estimate the variability in convective outflow through the use of the in-situ observations coupled to the trajectory analysis. The main aims of this study are to: (1) evaluate the capability of the model to reproduce the vertical structure of convective outflow and the presence of convectively processed layers above $355 \mathrm{~K}$ and, (2) identify the extent of such layers and compare with the observed impact of convection in the upper troposphere. In this respect these approaches are complementary with Law2010 analysing the interplay of largescale transport and convection and this paper examining the role of local deep convection in more detail.

\section{Observations}

The M55 Geophysica aircraft performed 5 local flights and 2 transfer flights in West Africa from 1 to 16 August 2006. The objective was to characterize the TTL composition under different regimes (local convection, background, large scale westerly flow, and long-range transport of biomass burning emissions). M55 observations show that the thermal tropopause was located at $375 \mathrm{~K}$ potential temperature level $(17 \mathrm{~km})$ and that TTL boundaries ranged between 350 and $420 \mathrm{~K}$. Moreover observations indicates the presence of enhanced aerosol due to convection in the lowermost TTL $(355 \mathrm{~K})$; further details are provided in Fig. 2 of Law 2010. The same paper reports the analysis of average profiles of aerosol and chemical tracers during the whole M55 campaign coupled to synoptic back trajectories showing that during three flights (7 August from 12:00 to 16:00 UTC, $8 \mathrm{Au}-$ gust from 12:00 to 16:00 UTC and 11 August from 14:00 to 18:00 UTC) there was a presence of organized convective systems either close to the flights or upwind over eastern and central Africa with a likely impact in the observed upper tropospheric composition. In the following subsections we present the satellite observations of deep convection and the observed vertical profiles of aerosol and chemical tracers for each one of the three selected flights. 


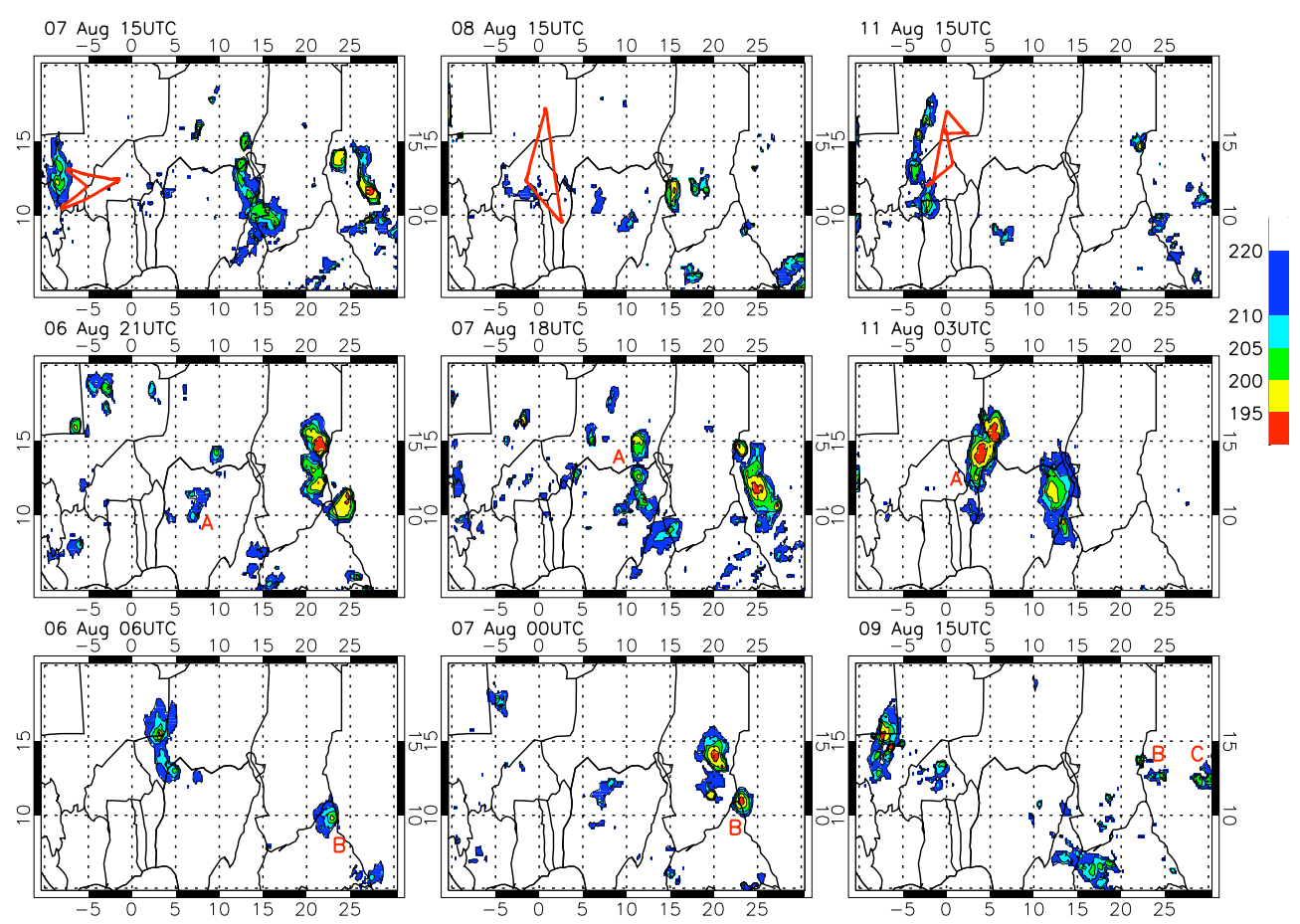

Fig. 1. METEOSAT cloud top brightness temperature time evolution prior to the M55 flight on 7 August 2006 (left panels), 8 August 2006 (central panels), and 11 August 2006 (right panels). Color scale indicates cloud top temperature expressed in K. Flight paths are shown by the red lines; red capital letters identify matches between back trajectories and deep convection as described in the text.

\subsection{Satellite observations}

In order to analyse the lifetime and position of Mesoscale Convective Systems (MCS) upwind and in proximity of the flight region, we use Cloud Top Brightness Temperature (CTBT) at $10.8 \mu \mathrm{m}$ measured by the SEVIRI instrument onboard the Meteosat Second Generation satellite (MSG). Synoptic back trajectories calculated from ECMWF data and originating from flight path are used to identify air masses likely influenced by convection. To do so, positions derived from back trajectories are matched with MSG CTBT to identify MCS outflows that likely influenced M55 observations. Figure 1 shows CTBT at the time of M55 flight (top row) and at the time of matches between back trajectories and observed deep convection for each event (central and bottom rows). A temperature threshold (CTBT $<220 \mathrm{~K})$ was applied to select deep convective clouds (Schmetz et al., 1997).

\subsubsection{August 2006}

Left column in Fig. 1 shows MSG CTBT on 6 August at 06:00 UTC, at 21:00 UTC and on 7 August at 15:00 UTC. Back trajectory matches with an MCS located in northern Nigeria the evening of 6 August, i.e. $18 \mathrm{~h}$ prior to the flight (labeled as A in Fig. 1, left column central panel) with minimum CTBT ranging between 205 and $210 \mathrm{~K}$. A second match is observed $33 \mathrm{~h}$ prior to the flight with an MCS in
South Chad (B, Fig. 1 left column, bottom panel) with minimum CTBT below $200 \mathrm{~K}$. Moreover, the western part of the flight (indicated with the red line in Fig. 1, top panel) was close to a dissolving intense MCS in Southern Mali.

\subsubsection{August 2006}

Central column in Fig. 1 shows the MSG CTBT on $7 \mathrm{Au}-$ gust at 00:00 UTC, 7 August at 18:00 UTC and on 8 August at 15:00 UTC. Back trajectory matches with a squall line between northern Nigeria and Niger late afternoon of 7 August, i.e. $21 \mathrm{~h}$ prior to the flight (labeled as A in Fig. 1, central column middle panel) with minimum CTBT ranging between 195 and $200 \mathrm{~K}$. A second match with an MCS in South Chad is observed $39 \mathrm{~h}$ prior to the flight (B, Fig. 1 central column, bottom panel) with minimum CTBT below 195 K. Sparse convective activity with CTBT higher than $210 \mathrm{~K}$ is observed simultaneously to the flight.

\subsubsection{August 2006}

Right column in Fig. 1 shows the MSG CTBT on 9 August at 15:00 UTC, 11 August at 03:00 UTC and on 11 August at 15:00 UTC. The flight was carried out in the outflow of a vast MCS observed above western Niger $12 \mathrm{~h}$ prior to the flight with CTBT lower than $195 \mathrm{~K}$ (labeled as A in Fig. 1, right column middle panel). The MCS propagated westward and 
was observed in its decaying phase west of the flight region at 15;00 UTC. A second match is observed $39 \mathrm{~h}$ prior to the flight with two MCSs (B and C, Fig. 1 right column, lower panel) with minimum CTBT above 200 .

\subsection{M55 observations}

In this work observations of aerosol backscatter ratio (BSR), aerosol depolarization $\left(\delta_{a}\right)$, ozone $\left(\mathrm{O}_{3}\right)$, water vapour $\left(\mathrm{H}_{2} \mathrm{O}\right)$, carbon dioxide $\left(\mathrm{CO}_{2}\right)$ and particle fine fraction $\left(\mathrm{N}_{6-14}\right)$ from 7, 8 and 11 August 2006 are presented. Measurements of $\mathrm{O}_{3}$ were made using FOZAN (Fast OZone ANalyzer, Yushkov et al. (1999)), $\mathrm{H}_{2} \mathrm{O}$ using FISH (Fast In-situ Stratospheric Hygrometer, Schiller et al. (2009)), $\mathrm{CO}_{2}$ using HAGAR (High Altitude Gas AnalyzeR, Volk et al. (2000)), NO using SIOUX (see Voigt et al. (2008) and references therein) CO using COLD (Cryogenically Operated Laser Diode, Viciani et al. (2008)), $\mathrm{N}_{6-14}$ using COPAS (COndensation PArticle counter Systems) (Borrmann et al. (2010)), BSR and $\delta_{a}$ by MAS (Multiwavelength Aerosol Scatterometer, Adriani et al. (1999)). Relative humidity with respect to ice freezing (RHI) is estimated from observed $\mathrm{H}_{2} \mathrm{O}$, temperature and pressure using the formula prescribed by the World Meteorological Organization and the Marti and Mauersberger (1993) formula for saturation pressure over ice. The description of the campaign and the overview of each flight is provided in Cairo et al. (2010) where a list of available observations are presented. Enhanced values of BSR indicate the presence of aerosols and values of $\delta_{a}$ above $10 \%$ indicate the presence of ice crystals (Cairo et al., 1999). The mechanism of cirrus formation in the uppermost troposphere is still matter of debate, in particular whether ice particles formation can be directly linked to deep convective systems (see for instance Pfister et al. (2001) and Mace et al. (2006)). The use of ice particles as tracer for convection may be ambiguous.

Ultrafine particles $\left(\mathrm{N}_{6-14}\right)$ are estimated as the difference between the concentration of particles larger than 6 $\mathrm{nm}$ and larger than $14 \mathrm{~nm}$; enhanced values of $\mathrm{N}_{6-14}$ (up to $1000 \mathrm{~cm}^{-3}$ ) indicate that formation must be recent because nucleation mode particles exist only for few hours to one day. Such values can be observed in recent outflow of deep convective clouds (Curtius, 2006). Observations of $\mathrm{O}_{3}, \mathrm{H}_{2} \mathrm{O}$, $\mathrm{CO}_{2}$ in air masses possibly influenced by local convection can be identified as deviations with respect to their average value assuming that air masses uplifted by convection are characterized by tracer concentrations close to those representative of the lower troposphere (Bertram et al., 2007). Alternatively, convective processing can act as an ozone source through lightning activity (Schumann and Huntreiser, 2007) with susbstantial production in the TTL (Riviere et al., 2006). As outlined in the introduction and discussed in Law2010, $\mathrm{O}_{3}$ in the UT can come from advection of pollutants sources so in that respect, and because of its relatively long lifetime, identification of local convection signatures is not straightforward. A non convective average profile, used to iden- tify observed outliers, was calculated from data collected on the 4 and 13 August flights. These flights were large-scale north-south transects and provide information on the background conditions in the uppermost troposphere as shown by Law2010 where background observations are compared to average convective profiles.

Figure 2 shows the M55 observations on 7 August; there and in the following Figs. 3 and 4 dashed lines represent nonconvective average profile plus (and minus) one standard deviation; the flight was carried out between $11^{\circ} \mathrm{N}$ and $13^{\circ} \mathrm{N}$ and sampled a region east of the MCSs indicated by (1) in the top left panel of Fig. 1. Two layers of enhanced aerosol depolarization were observed at 350 and $370 \mathrm{~K}$. Observations with enhanced aerosol concentrations (BSR $>1.2$ ) are labeled with open triangles. It can be seen that particles are in the solid phase since $\delta_{a}$ is larger than $20 \%$ when BSR is enhanced. Total water is enhanced with respect to the average profile in both aerosol layers where RHI exceeds $100 \%$. $\mathrm{O}_{3}$ mixing ratios range between 45 and $60 \mathrm{ppbv}$ at $350 \mathrm{~K}$ (where BSR is enhanced) and increase steadily above $360 \mathrm{~K} . \mathrm{N}_{6-14}$ shows enhanced values (above $100 \mathrm{~cm}^{-3}$ ) in the lower aerosol layer. In the higher layer, enhanced BSR were observed together with $\mathrm{O}_{3}$ mixing ratios of $80 \mathrm{ppbv}$ which is above the values measured below $360 \mathrm{~K} . \mathrm{CO}_{2}$ data were not available for this event.

Figure 3 shows the observations for 8 August; the M55 performed a north-south cross section between $8^{\circ} \mathrm{N}$ and $18^{\circ} \mathrm{N}$ (see Fig. 1, top-central panel), and measurements are likely to have been influenced by MCS outflow $20 \mathrm{~h}$ prior to observation. Enhanced BSR and $\delta_{a}$ were observed between $11^{\circ} \mathrm{N}$ and $14^{\circ} \mathrm{N}$ below $355 \mathrm{~K}$, at $17^{\circ} \mathrm{N}$ at $365 \mathrm{~K}$ and at lower latitudes $\left(11^{\circ} \mathrm{N}\right)$ between 370 and $375 \mathrm{~K}$. In the lower layer, $\mathrm{H}_{2} \mathrm{O}$ mixing ratios are much larger ( 15 to $200 \mathrm{ppmv}$ ) at $14^{\circ} \mathrm{N}$ with respect to $11^{\circ} \mathrm{N}$. Values of RHI are above $100 \%$ inside the three aerosol layers. $\mathrm{O}_{3}$ shows mixing ratios ranging between 40 and 70 ppbv below $360 \mathrm{~K}$ that corresponds to the enhanced BSR (triangles) with lower mixing ratios $\left(\mathrm{O}_{3}<50 \mathrm{ppbv}\right)$ observed at lower latitudes $\left(<12^{\circ} \mathrm{N}\right) \cdot \mathrm{CO}_{2}$ concentrations are quite variable below $350 \mathrm{~K}$ (larger values at $11^{\circ} \mathrm{N}$ than at $14^{\circ} \mathrm{N}$ ) and steadily increase above. Slightly reduced $\mathrm{CO}_{2}$ concentrations were observed between 365 and $375 \mathrm{~K}$. This can be interpreted as a signature of convective outflow that transport depleted $\mathrm{CO}_{2}$ from below. In fact $\mathrm{CO}_{2}$ mixing ratios are reduced above continents due to vegetation uptake; moreover, since convection in West Africa has a marked daily cycle with maxima in the evening and during night, when mixing layer $\mathrm{CO}_{2}$ is around its minimum, convective uplift can be identified as negative anomaly with respect to the average vertical profile.

The aerosol layer at $365 \mathrm{~K}$ is also associated with enhanced $\mathrm{H}_{2} \mathrm{O}$ (15 ppmv) and saturated RHI while no clear signature in $\mathrm{CO}_{2}, \mathrm{CO}$ and $\mathrm{O}_{3}$ is visible. The highest layer at $372 \mathrm{~K}$ is associated with enhanced $\mathrm{H}_{2} \mathrm{O}$ and RHI $>100 \%$ while $\mathrm{CO}_{2}$ does not show any deviation with respect to the average profile. $\mathrm{N}_{6-14}$ cannot be estimated since 

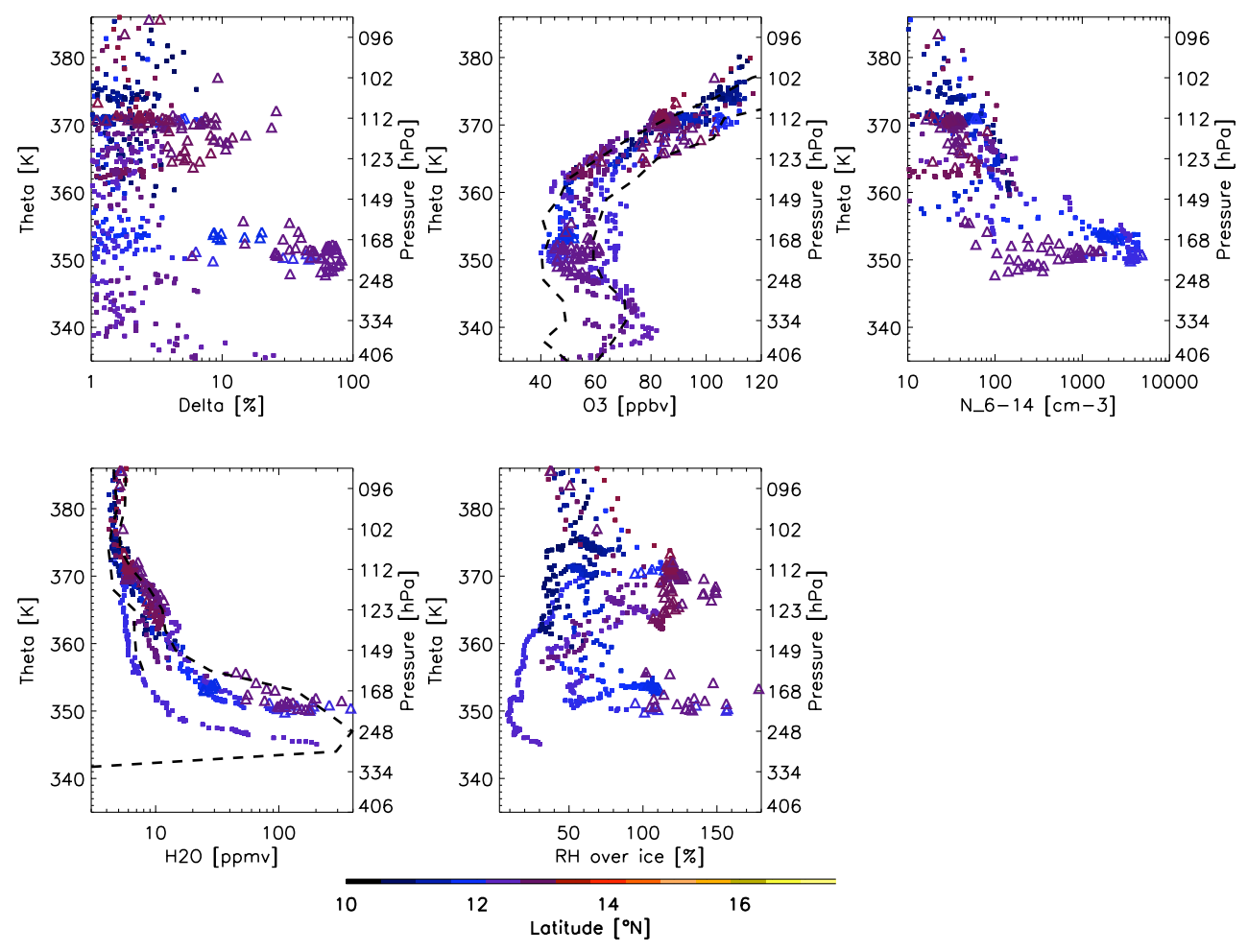

Fig. 2. Vertical profiles of observed depolarization $\delta_{a}$, ozone $\mathrm{O}_{3}$, carbon dioxide $\mathrm{CO}_{2}$, particle fine fraction $\mathrm{N}_{6}-\mathrm{N}_{14}$, water vapour $\mathrm{H}_{2} \mathrm{O}$ and relative humidity with respect to ice $\mathrm{RH}$ on 7 August 2006. Colors indicate the measurement latitude; triangles indicate the observations within air parcels containing aerosol $(\mathrm{BSR}>1.2)$. Dashed lines indicate average values $+/-$ one standard deviation of $\mathrm{O}_{3}$, $\mathrm{CO}_{2}$ and $\mathrm{H}_{2} \mathrm{O}$.

observations have a partial coverage. However the analysis of total number of particles available above $360 \mathrm{~K}$ height do not show any increase in concentration due to nucleation event.

Figure 4 shows the observations for 11 August, taken between $12^{\circ} \mathrm{N}$ and $16^{\circ} \mathrm{N}$ (see Fig. 1, bottom right panel). Several layers with enhanced BSR and $\delta_{a}$ are observed up to $376 \mathrm{~K} . \mathrm{H}_{2} \mathrm{O}$ is enhanced in the $355-365 \mathrm{~K}$ layer at $16^{\circ} \mathrm{N}$ of latitude where no particles were observed while RHI were unsaturated. Increased $\mathrm{H}_{2} \mathrm{O}$ was also observed between 365 and $380 \mathrm{~K}$ at $14^{\circ} \mathrm{N}$ of latitude at the same time as enhanced ice particles. $\mathrm{N}_{6-14}$ is higher (with values between 100 and $3000 \mathrm{~cm}^{-3}$ ) up to $370 \mathrm{~K}$ and larger values are observed with background BSR. Moreover, large $\mathrm{N}_{6-14}$ is in general correlated to depleted $\mathrm{CO}_{2} . \mathrm{O}_{3}$ mixing ratios range between 45 and 60 ppbv below $355 \mathrm{~K}$. Between 355 and $370 \mathrm{~K} \mathrm{O}_{3}$ is highly variable ( 45 to $90 \mathrm{ppbv}$ ) depending on the sampled latitude and increases steadily above that level. $\mathrm{CO}_{2}$ shows constant mixing ratios below $355 \mathrm{~K}$ ( $377 \mathrm{ppmv})$ and reduced mixing ratios ( $374 \mathrm{ppmv}$ ) from 355 to $368 \mathrm{~K}$.

From the data collected during these 3 flights, it is evident that convective impact is visible below $355 \mathrm{~K}$ with simultaneous enhancements in water vapour, BSR and aerosol fine fraction, together with reduced concentrations of $\mathrm{CO}_{2}$. Enhanced concentrations of ice particles were also observed up to these altitudes indicating that in the main outflow they were formed as a result of deep convection. Above $355 \mathrm{~K}$ several layers of particles under saturated conditions were observed. During 7 and 8 August these layers were less ubiquitous with respect to the main outflow below $355 \mathrm{~K}$ and were, on average, not correlated to a clear signature on chemical tracers. Nevertheless, small and sporadic signatures in $\mathrm{CO}_{2}$ (and $\mathrm{NO}$ - not reported here) were observed above the main convective outflow level. Homan et al. (2010) presents the analysis of $\mathrm{CO}_{2}$ profiles for 8 August and indicates that "tape recorder" signal is less compact than as during the other flights which might be an indication of convective transport while on 11 August the $\mathrm{CO}_{2}$ depletion can be attributed to the effect of local deep convection. In fact, observations on 11 August show a different picture with ice aerosol observed throughout the vertical profile up to $375 \mathrm{~K}$. In this case, convective impact reached up to 365 and $370 \mathrm{~K}$ based on depleted $\mathrm{CO}_{2}$ concentrations and the presence of ultrafine particles. $\mathrm{O}_{3}$ mixing ratios are variable below $355 \mathrm{~K}$ and increase above during the first two flights ( 7 and $8 \mathrm{Au}-$ gust) while the last analyzed event (11 August) shows a nearly constant profile up to $360 \mathrm{~K}$. As observed on $8 \mathrm{Au}-$ gust, $\mathrm{O}_{3}$ in the lowermost TTL can present a latitudinal gradient that, according to Law2010, can be attributed to higher $\mathrm{NO}_{\mathrm{x}}$ emissions and/or lightning $\mathrm{NO}_{\mathrm{x}}$ that might be more 

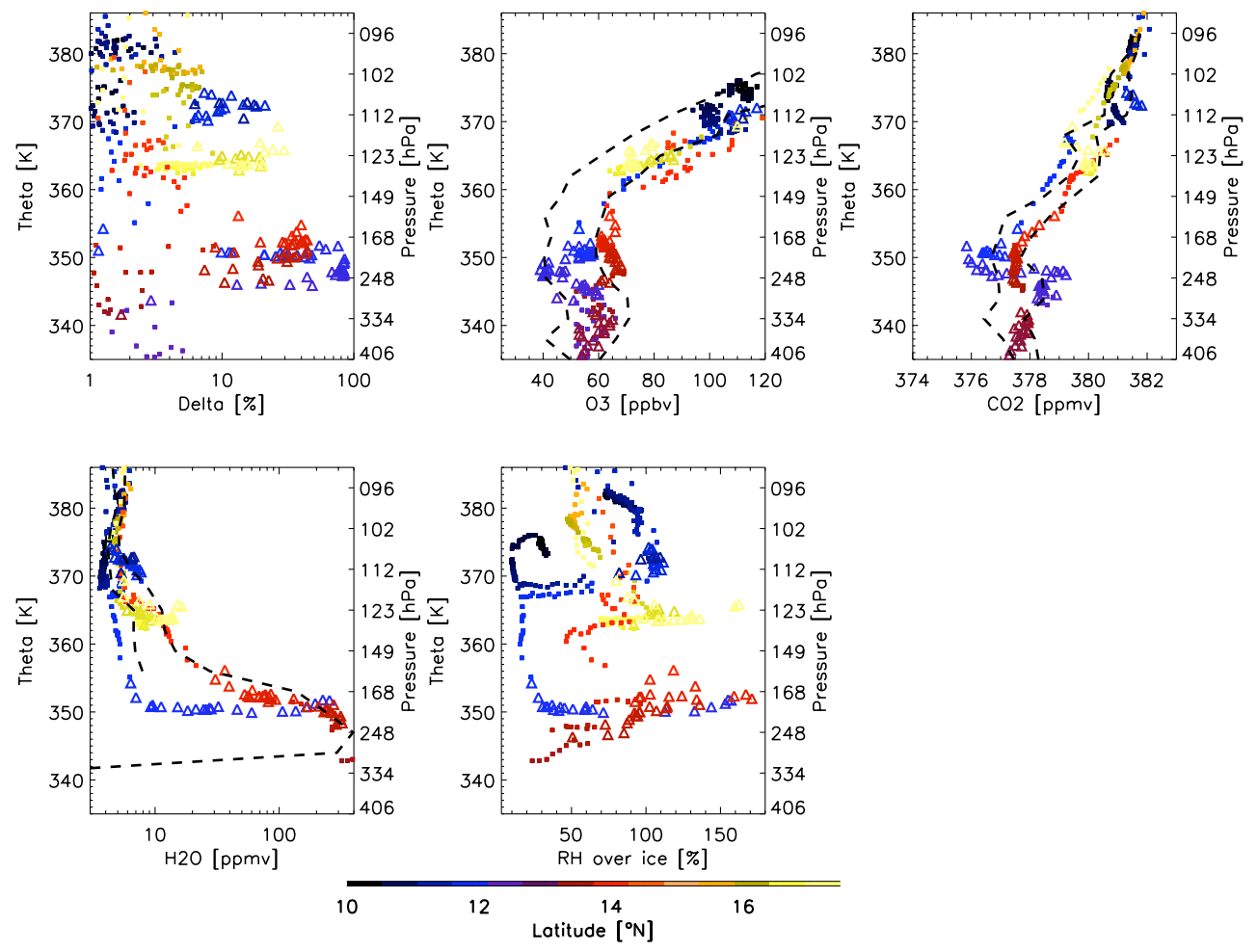

Fig. 3. As Fig. 2 but for 8 August 2006

relevant further north and directly related to the main latitude of convective activity. The role of long-range transport on the variability of chemical tracers in the TTL during AMMA is presented in Law2010, showing that local sources of $\mathrm{O}_{3}$ over West Africa can be convectively uplifted and mix with air masses advected from upwind regions in the upper TTL; this leads to a less straightforward identification of convective signatures in $\mathrm{O}_{3}$ in the West African troposphere with respect to oceanic convection as discussed for instance in Folkins et al. (2002). The same analysis shows also evidence for enhanced $\mathrm{CO}_{2}$ in convection further east in air masses originating from central African BB emission regions.

Observations of ice particles and outliers in chemical species (and ultrafine particles) are often uncorrelated in the layer between the average convective outflow at $355 \mathrm{~K}$ and the tropopause, leading to the qualitative conclusion that this region is composed of air masses with different processing and lifetimes in the TTL. To quantify the convective transport during the M55 observations we will use now a mesoscale model as detailed below.

\section{Mesoscale simulations}

BOLAM (BOlogna Limited Area Model) is a meteorological mesoscale model based on primitive equations in the hydrostatic approximation and uses wind components $\mathrm{u}$ and $\mathrm{v}$, potential temperature $\theta$, specific humidity q and surface pres- sure $\mathrm{p}_{s}$ and includes the advection of passive tracers. Variables are defined on hybrid coordinates and they are distributed on a non-uniformly spaced Lorenz grid. The horizontal discretization uses geographical coodinates, with latitudinal rotation on an Arakawa C-grid. The model implements a Weighted Average Flux (WAF) scheme for the three dimensional advection. The lateral boundary conditions are imposed using a relaxation scheme that minimises wave energy reflection. Deep convection is parameterized using the scheme of Kain-Fritsch (Kain, 2004). The boundary layer scheme is based on the mixing length assumption and on the turbulent kinetic energy explicit prediction; the surface turbulent fluxes are computed according to the Monin-Obukhov similarity theory. The parameterization of the effects of vegetation and soil processes is based on water and energy balance in a four layer soil model, and includes diagnostic computation of skin temperature and humidity, seasonally dependent vegetation effects, evapo-transpiration and interception of precipitation. The radiation is computed with a combined application of the scheme from Ritter and Geleyn (1992) and that from the operational ECMWF model (Morcrette et al., 1998). BOLAM uses a microphysical scheme derived from Schultz (1995) and described in Drofa (2003) that treats five categories of condensate: liquid cloud, pristine ice (cloud ice), rain, snow and graupel. The amount of pristine ice and the crystal growth by water vapour diffusion are both dependent on the supersaturation level and are parameterized via 

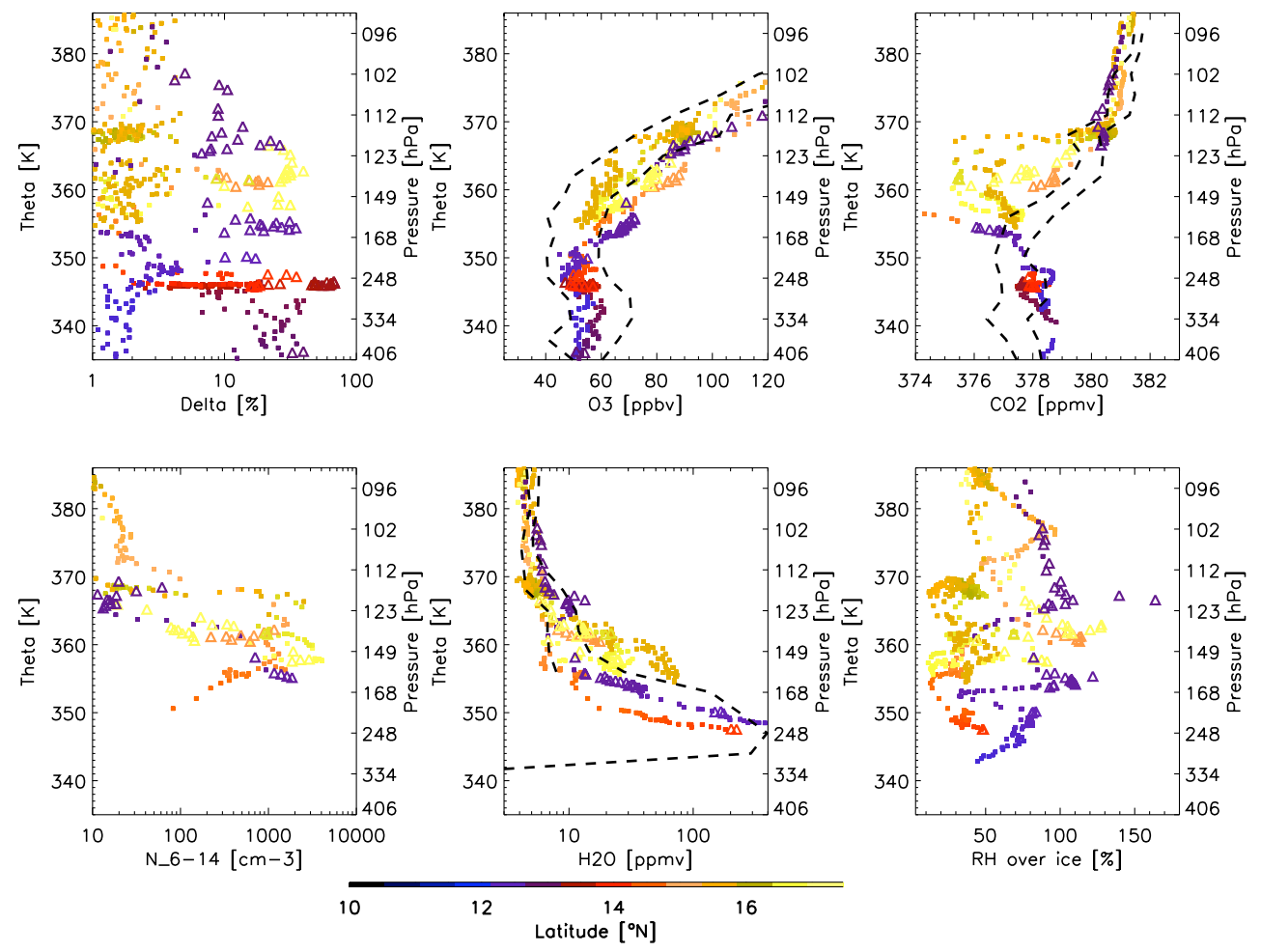

Fig. 4. As Fig. 2 but for 11 August 2006

the average mass of a single nucleated pristine crystal and a conversion rate control parameter. Ice is removed through sedimentation, conversion to graupel, melting and evaporation. Further details about the model are given in Buzzi and Foschini (2000). The model is based on a 38 vertical level hybrid coordinate system, from the ground to the top of the atmosphere $(0.1 \mathrm{hPa})$ with denser levels near the ground, leading to a vertical resolution of $800 \mathrm{~m}$ in the upper troposphere. The horizontal domain has $235 \times 235$ grid points or $24 \mathrm{~km}$ horizontal resolution covering the whole Sahelian transect $\left(15^{\circ} \mathrm{W}\right.$ to $40^{\circ} \mathrm{E}$ in longitude and 0 to $25 \mathrm{~N}$ in latitude). In this study, the simulation was started at 00:00 UTC on 4 August 2006 and run until 00:00 UTC on 14 August 2006. The model was continuously nudged with brightness temperatures at $10.8 \mu \mathrm{m}$ from Meteosat Second Generation (MSG) satellite in order to accurately reproduce the evolution of mesoscale convective systems as already described in Orlandi et al. (2010).

\subsection{Validation}

The nudged BOLAM simulation was evaluated by comparing model derived CTBT and the satellite observations shown in Fig. 1. Figure 5 shows, for the same times reported in Fig. 1, model CTBT calculated with the RTTOV-8 (Saunders and Brunel, 2004) radiative transfer model, using BOLAM water vapour, temperature and hydrometeors pro- files. Similarly to Fig. 1, only regions with CTBT $<220 \mathrm{~K}$ are plotted. Overall the comparison between observed and simulated CTBT shows that the BOLAM model correctly reproduces the location and temperature range of convective clouds top even if it underestimates the area of convection. In particular there is a good agreement with the convective activity influencing the area sampled by M55 measurements, discussed in Sect. 2.1.

BOLAM CTBTs prior to 7 August (shown in left column of Fig. 5) correctly reproduce the observed MCSs in Fig. 1 and also the convection upwind of measurement area which developed 18 and $33 \mathrm{~h}$ before the flight took place (labeled A and B in Fig. 1). Model brightness temperatures for both systems range between 200 and $195 \mathrm{~K}$, similarly to MSG observations.

On the 8 August, BOLAM CTBTs (central panels of Fig. 5) show the squall line (labeled as A in Fig. 1) and the convective system (labeled as B) $39 \mathrm{~h}$ before the flight. The modeled CTBT for MCS B is slightly lower than observed by MSG. Right column of Fig. 5 shows CTBT prior to 11 August. The evolution and CTBT of MCS labeled as (A) is correctly reproduced, although modelled clouds appear to be more scattered. The aerosol backscatter data from the Cloud-Aerosol Lidar and Infrared Pathfinder Satellite Observation (CALIPSO), shown in Fig. 6, sampled the Sahelian region at longitudes ranging between $3^{\circ} \mathrm{E}$ and $5^{\circ} \mathrm{E}$ on 11 August at 01:30 UTC. It shows a deck of solid particles up 


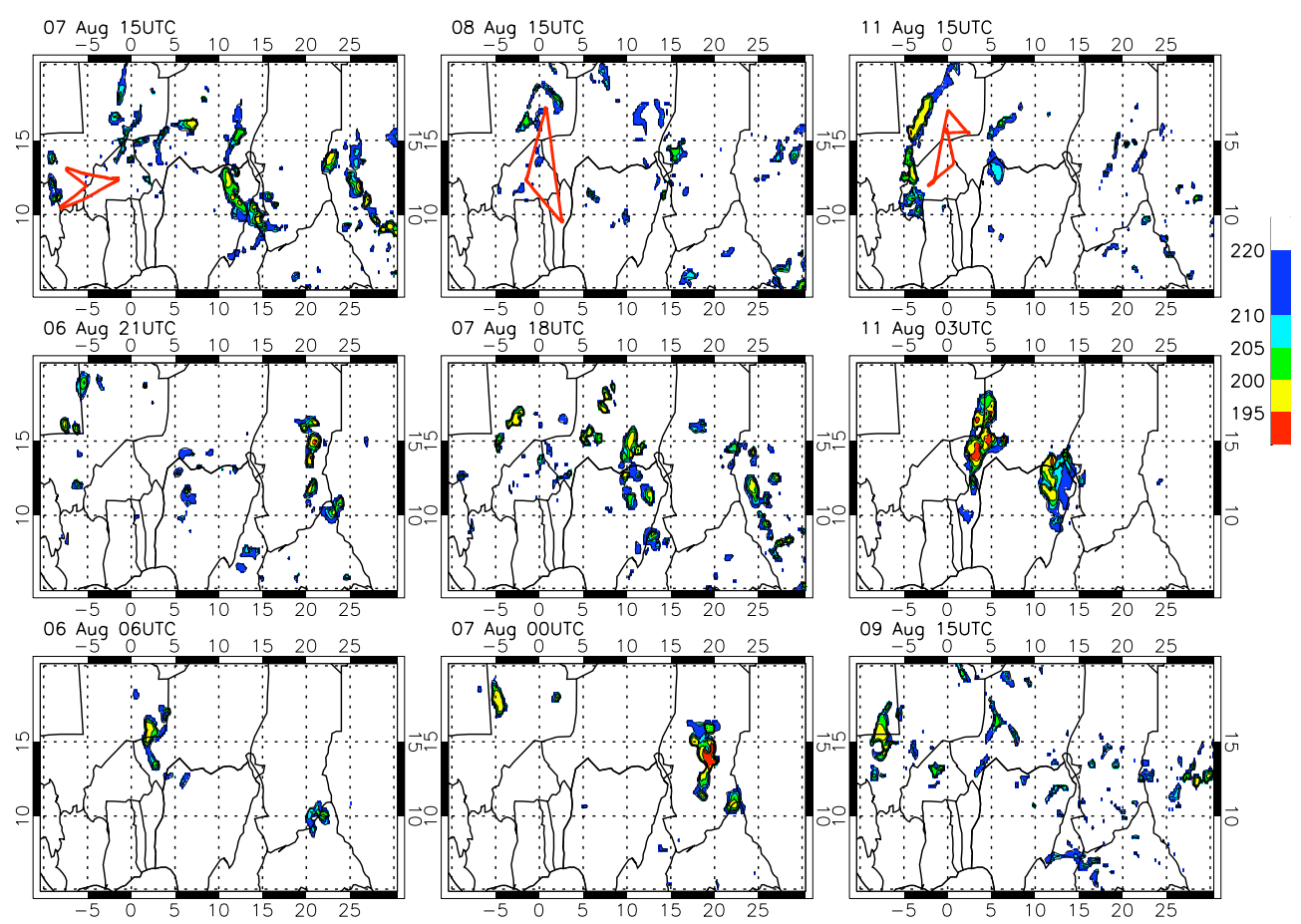

Fig. 5. As Fig. 1 but for the BOLAM model

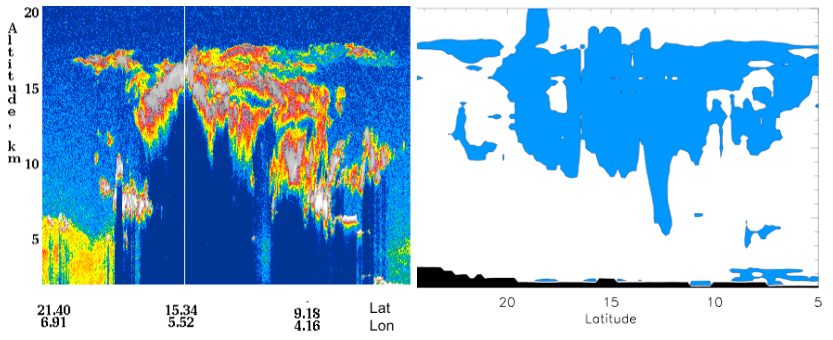

Fig. 6. Left: CALIPSO aerosol backscatter observed at 01:30 UTC on 11 August. Aerosol observations (not shown) shows that aerosol are in solid phase. Right: relative humidity with respect to ice estimated from BOLAM along the CALIPSO overpass. Shaded area shows where relative humidity exceeds $100 \%$.

to $17 \mathrm{~km}(380 \mathrm{~K})$ between $7^{\circ} \mathrm{N}$ and $18^{\circ} \mathrm{N}$ and vast deep convection area reaching up to $16.5 \mathrm{~km}(370 \mathrm{~K})$ around $15^{\circ} \mathrm{N}$ corresponding to MCS (A) in Fig. 1 right column. BOLAM relative humidity along the CALIPSO overpass is reported in right panel of Fig. 6, showing a good agreement with observations: the model indicated that saturation occurs up to $17 \mathrm{~km}$, the level of average tropopause during August 2006 (Cairo et al., 2010; Law et al., 2010), in correspondance with the CALIPSO cloud top. The latitudinal extent of the MCS is also well captured, with a slight northward shift in the BOLAM model, also visible from the comparison of system (A) reported in Figs. 1 and 5, right column. A thorough comparison of the BOLAM simulations for this event and the improvement due to nudging to satellite observations is reported in Orlandi et al. (2010). In general, BOLAM generates less organized convective systems with respect to satellite observations even if the position and the temporal evolution of MCSs are well reproduced. Simulations also show a coherent transport behavior in the presence of MCSs generated by nudging, with increased divergence in the upper troposphere (Orlandi et al., 2010). Therefore, the transport by convective uplift and outflow can be estimated from the BOLAM simulation with an accuracy considered adequate enough to be used for the interpretation of the M55 data.

\subsection{Convective tracer}

In order to quantify convective uplift of lower tropospheric air with the BOLAM model, a set of Eulerian tracers are included in the run. Tracer are injected instantaneously with a timestep of $6 \mathrm{~h}$ in the two lowest model levels over the whole domain with a mass mixing ratio $\chi^{i}(\phi, \lambda, \theta)$ of 10 units where $\phi, \lambda, \theta$ are the model longitude, latitude and potential temperature level. They are treated as passive tracers for $6 \mathrm{~h}$ following the injection and then removed from the mixed layer. The mixed layer top is the upper boundary of the region where rapid mixing occurs and can be defined as an abrupt decrease tracer mixing ratios. This approach has been previously used by Mullendore et al. (2005) for a single tracer to estimate the upward mass fluxes in deep convection from mesoscale model. Here, we extend this approach considering 31 independent tracers, injected from 4 August at 
00:00 UTC until the end of period under analysis (11 August at 18:00 UTC). We remove the tracers below $400 \mathrm{hPa}$, that is above the maximum mixed layer top and below the minimum height of deep convective outflow as reproduced by the BOLAM model. Tracer profiles (not shown) indicate a mixing ratio minimum, that appears at $400 \mathrm{hPa} 3 \mathrm{~h}$ after emission, above the region of rapid vertical mixing uplift tracer (that can reach up to $500 \mathrm{hPa}$ ) while the effect of convective uplift is visible above $300 \mathrm{hPa}$. So each tracer can be uplifted by convection only during the $6 \mathrm{~h}$ after emission, when it resides in the mixed layer. For each of the convective flights analysed, only the twelve tracer fields emitted in the previous $72 \mathrm{~h}$ have been considered. In order to quantify the amount of mixed layer air uplifted by convection during the i-th $6 \mathrm{~h}$ interval, the convective fraction of the i-th tracer $f_{c}^{i}$ can be estimated for each model grid point and for each timestep $t$ analogously to that reported in Bertram et al. (2007) as:

$f_{c}^{i}(\phi, \lambda, \theta, t)=\frac{\chi^{i}(\phi, \lambda, \theta, t)}{\chi_{\mathrm{ML}}^{i}}$

where $\chi_{\mathrm{ML}}^{i}$ is the tracer mean mass mixing ratio in the mixed layer and $i$ is the tracer index representative of emission time. The mixed layer top is estimated for each model grid point as the minimum of the vertical gradient of tracer mixing ratio vertical profile. The use of different tracers allows estimation of the age spectrum $F_{c}(\phi, \lambda, \theta, t)$ of convective uplift from mixed layer as:

$F_{c}(\phi, \lambda, \theta, t, T)=\sum_{i=1}^{T} f_{c}^{i}(\phi, \lambda, \theta, t)$

where $T$ is the time in hours of tracer emission prior to the analyzed time. The total convective fraction $f_{c}$, that is used to quantify the amount of mixed layer air regardless of the uplift time, is estimated as the sum of the $f_{c}^{i} 72 \mathrm{~h}$ prior to each analysed time $t$, i.e. $F_{c}(\phi, \lambda, \theta, t, T=72)$. We estimate the convective time $T_{c}(\phi, \lambda, \theta, t)$ as the time when $75 \%$ of total tracer concentration is present for each model grid point and time:

$F_{c}\left(\phi, \lambda, \theta, t, T_{c}\right)=0.75 \cdot F_{c}(\phi, \lambda, \theta, t, T=72)$

and represents the time (prior to the analyzed time $t$ ) when dominant convective uplift occurred. The results are slightly sensitive to changes in the threshold (60\% to $75 \%)$; a positive bias (for lower thresholds) is visible especially for older outflow in limited regions but the spatial distribution remains unchanged.

\section{Convective outflow from tracer simulations}

We report the spatial distribution of the model diagnostics described above for each M55 flight under analysis. Figure 7 shows the convective fraction $f_{c}$ and the convective
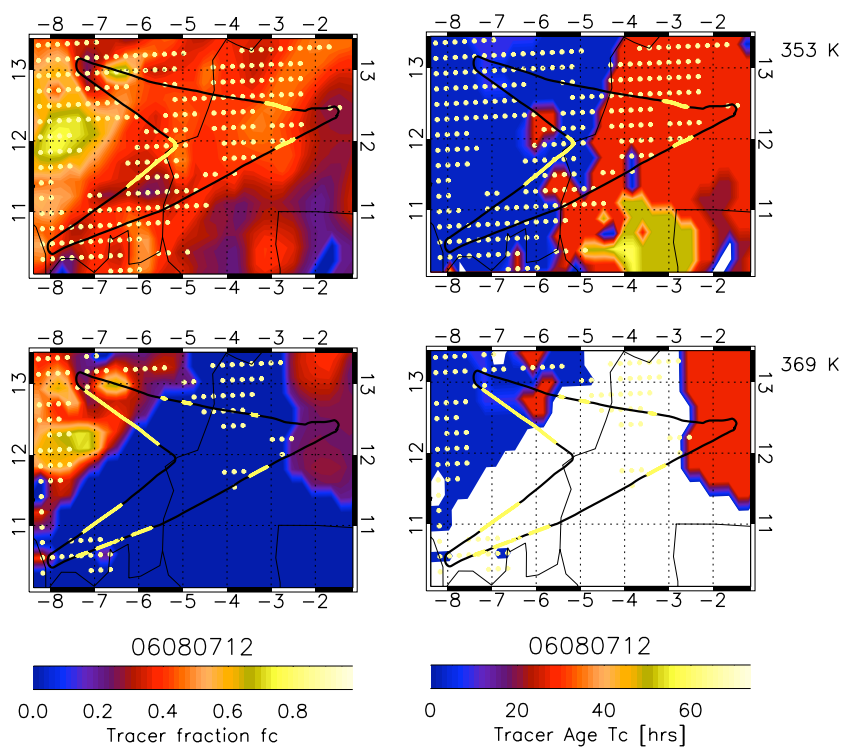

Fig. 7. Left: maps of $f_{c}$ estimated from the BOLAM model (see text for definition) for two theta layers (368-369 K above the main convective levels and at 352-354 K) for 7 August 2009 at 15:00 UTC. Yellow dots indicates where BOLAM $\mathrm{RH}_{\text {ice }}$ exceeds $100 \%$. The M55 path is reported in the plot: yellow thick lines indicates the part of flight occurring at the theta level reported in the figure. Right: same as left but for $t_{c}$.

time $T_{c}$ on 7 August at 15:00 UTC for two $\theta$ layers at $353 \mathrm{~K}$ (representative of the main outflow) and $369 \mathrm{~K}$ (close to the tropopause). The whole flight area in the lower layer is characterized by values of total convective tracer ranging between 0.1 and 0.7 indicating that convective uplift has a likely impact. Convective age is highly variable with lower values (few hours) in the western part of the analyzed domain and higher values ( 24 to $48 \mathrm{~h}$ ) in the eastern part indicating that air parcels were uplifted at different times. Based on the tracer analysis, more recent uplift occurs close to the convective system observed west of the flight region (see Fig. 1 and Fig. 5 top left panel) while more aged uplift occurs at two distinct times, in reasonable agreement with the conclusions drawn in Sect. 2.1.1. BOLAM also shows the presence of saturated air $\left(\mathrm{RH}_{\text {ice }}>100 \%\right)$ (yellow shaded area) corresponding to convective outflow with $T_{c}$ less than $24 \mathrm{~h}$. The distribution of $f_{c}$ and $T_{c}$ in the upper layer $(369 \mathrm{~K})$ shares similar characteristics with the lower layer but with a smaller area with significant convective impact (i.e. $f_{c}>0.1$ ) confined to the east and west boundaries of flight region.

Figure 8 shows the same set of diagnostics for $8 \mathrm{Au}$ gust. Although a similar picture to the previous event can be inferred, the impact of deep convection in the higher layer $(369 \mathrm{~K})$ is larger during this event. The model shows the co-existence of air masses with different convective age $T_{c}$ with older uplift in the higher layer. Higher convective 

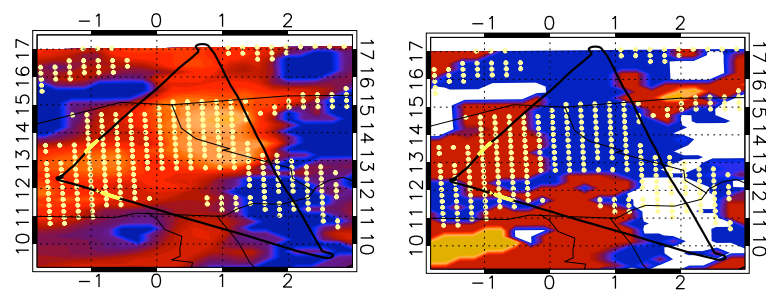

$353 \mathrm{~K}$
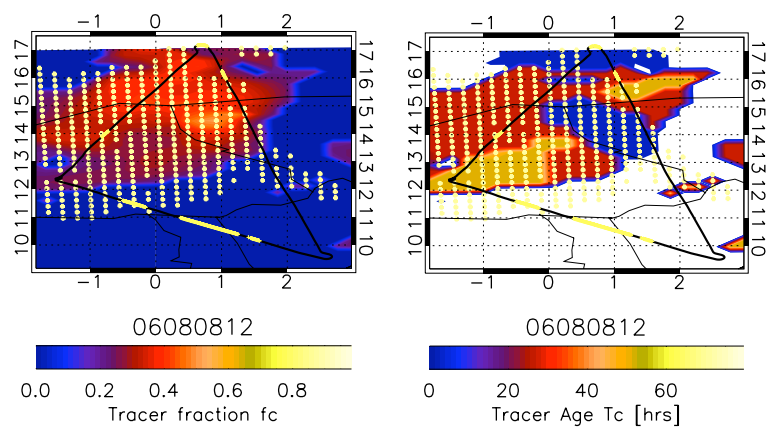

Fig. 8. As Fig. 7 but for the 8 August 2006 at 15:00 UTC .

fraction occurs in the northern part of the domain positively correlated to the observed $\mathrm{O}_{3}$ latitudinal variability reported in Fig. 3 with higher values of $\mathrm{O}_{3}(65 \mathrm{ppbv})$ observed north of $14^{\circ} \mathrm{N}$. Saturated air (yellow shade) is large and is present also in the upper layer located close to the outflow.

The results for 11 August (Fig. 9) show a large convective impact in both 352 and $365 \mathrm{~K}$ layers in the western part of the flight area, mostly related to uplift occurring in the large MCS labeled by (1) in Fig. 1 that is correctly reproduced by BOLAM (Fig. 5, right column). $T_{c}$ is lower than previous events, ranging between 6 and $20 \mathrm{~h}$, with values higher that $24 \mathrm{~h}$ only in the eastern part of the domain at $365 \mathrm{~K}$. Both layers are characterized by large areas of saturated air. In the lower level saturation occurs in the western part of the domain where older convection has a likely impact.

Overall, the analysis also shows that modeled convection has an important impact on the $353 \mathrm{~K}$ layer. At $365-369 \mathrm{~K}$, convective transport influence is visible to a smaller extent. Moreover, the convective age (as given by $T_{c}$ values) is variable showing that air masses influenced by very recent convection $\left(T_{c}<24 \mathrm{~h}\right)$ coexist (especially at higher altitudes) with air masses influenced by older convection $\left(T_{c}>48 \mathrm{~h}\right)$ which likely formed to the east over central the Sahelian region above northern Nigeria and southern Chad.

\section{Comparison with observations}

Since modeled and observed ice particle presence can also provide useful information, two additional diagnostics were defined to estimate model ice clouds and the extent to which such clouds might have been influenced by deep convection.
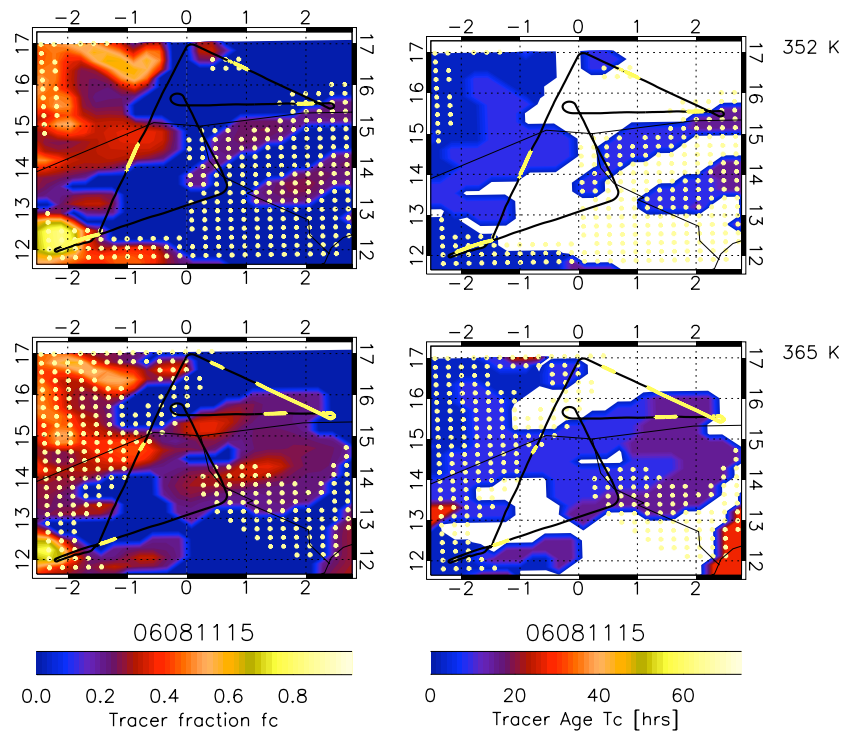

Fig. 9. As Fig. 7 but for the 11 August 2006 flight.

- The ice fraction, $f_{i}(\theta, t)$, is the fraction of model grid points with values of $\mathrm{RHI}>100 \%$

- The convective fraction of ice, $f_{\text {ic }}$, is the fraction of model grid points with values of RHI $>100 \%$ and with a total tracer concentration $F_{c}(\phi, \lambda, \theta, t, T=72)$ greater than 0.1

We focus now on the vertical structure of convective outflow in the upper troposphere. The model diagnostics are averaged in latitude and longitude over the flight area shown in Figs. 7-9 and in the vertical over $12 \theta$-levels with a vertical resolution comparable to the model. In order to perform a comparison of the modeled and the observed vertical profiles, a set of diagnostics analogous to those derived from BOLAM output are applied to measurements: (1) $f_{\mathrm{BSR}}$ is the fraction of observations with BSR $>1.2$ and describes the vertical distribution of ice clouds to be compared with $f_{i}$; (2) $f_{\mathrm{CO}_{2}}$ is the fraction of observations with $\mathrm{CO}_{2}$ concentrations lower than the average value minus its standard deviation and describes the possible impact of deep convection on $\mathrm{CO}_{2}$ profiles. Vertical profiles of diagnostics are plotted in Fig. 10: observation-derived ones are colored in red and model derived in blue. The vertical profile of $f_{c}$ is shown by the rightmost curve of $F_{c}(\theta, T)$ contours.

On 7 August the BOLAM convective fraction $f_{c}$ has a maximum of 0.4 at $350 \mathrm{~K}$ in agreement with observations that show a similar fraction of aerosol measurements at the same height; $f_{c}$ decreases rapidly with height becoming small $(<0.1)$ above $370 \mathrm{~K}$. The convective age spectra indicates that uplift occurred at three different times: less than $6 \mathrm{~h}$, approximately at $31 \mathrm{~h}$ and more than $48 \mathrm{~h}$ before the flight; recent uplift, likely originating from the convective 

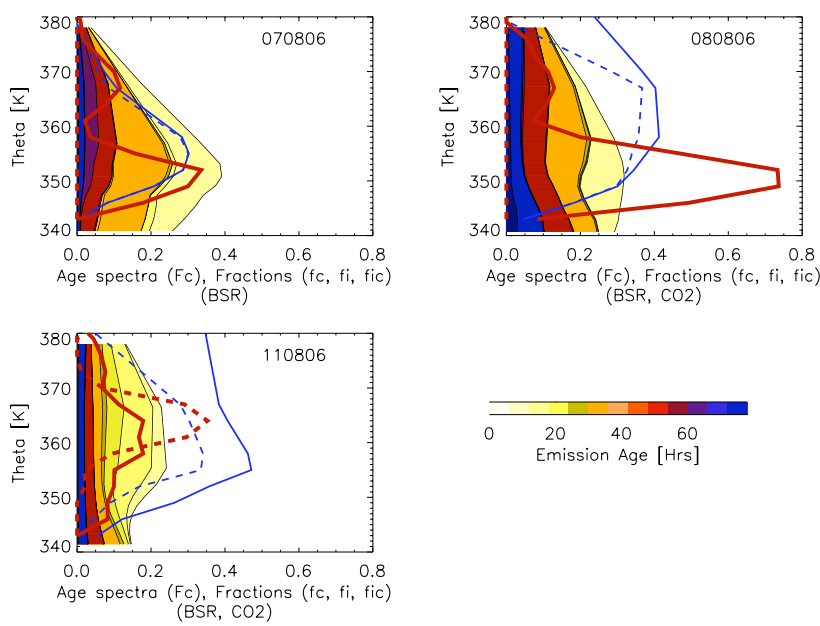

Fig. 10. Vertical profiles of the diagnostics described in the text. Model-derived ones are plotted in blue, observation-derived in red. Left column: BOLAM ice fraction $f_{i}$ (solid blue line) and convective ice fraction $f_{i c}$ (dashed blue line); observed aerosol fraction $f_{\mathrm{BSR}}$ (dotted red line), Right column: convective fraction $f_{c}$; observed fraction of outliars in $\mathrm{CO}_{2} f_{\mathrm{CO}_{2}}$ plotted as dashed red line; $f_{\mathrm{BSR}}$ is also plotted to be compared with $f_{c}$. Top panels are for 7 August, middle for 8 August and bottom for 11 August.

system west of the flight path shown in Fig.1, has a maximum impact at $350 \mathrm{~K}$ in the main convective outflow. Above, older uplift $(>48 \mathrm{~h}$ ) becomes dominant. The vertical profile of $f_{\mathrm{BSR}}$ for 7 August flight (Fig. 10, upper left panel, red solid line) shows the presence of two distinct layers (below $360 \mathrm{~K}$ and at $367 \mathrm{~K}$ ) as shown in Fig. 2. The model-derived vertical profiles of $f_{\text {ice }}$ (left panel, solid blue line) and $f_{\text {ice }}^{c}$ (left panel, dashed blue line) indicate that BOLAM predicts the presence of ice clouds in the whole convective layer that are formed inside air masses uplifted by deep convection. In the uppermost layer, where enhanced depolarization was observed, BOLAM reproduces a smaller amount of ice clouds in connection to the older convective uplift.

On 8 August (middle panel) the vertical structure of $f_{\mathrm{BSR}}$ is similar to the previous day but, in this case, BOLAM shows a less steep decrease in $f_{c}$ with height; enhanced $f_{i}$ is simulated up to the tropopause level in agreement with observations that indicate several layers of ice particles up to $375 \mathrm{~K} . f_{i c}$ is equal to $f_{i}$ below $355 \mathrm{~K}$ indicating that model ice clouds were formed in the convective outflow. Above that level the BOLAM model shows the presence of ice particles also in upper tropospheric air masses not originating from convective outflow. Above $370 \mathrm{~K}$ the model shows that ice forms predominantly in the uppermost troposphere and is uncorrelated to the convective uplift. Analogously to the previous event, recent uplift is confined below $355 \mathrm{~K}$ and above that level uplift occurred more than $24 \mathrm{~h}$ prior to the flight.

On 11 August (lower panel) the model shows that $F_{c}$ reaches quasi-constant values up to $370 \mathrm{~K}$ indicating that convective impact extended higher up in altitude with respect to the 2 previous events. Convective outflow is mainly composed of air mass recently uplifted $(<24 \mathrm{hrs})$. Nevertheless, the presence of older air masses (up to $72 \mathrm{~h}$ ) cannot be considered negligible throughout the vertical profile. BOLAM shows also the presence of a thick ice cloud layer (peaking at $360 \mathrm{~K}$ ) in agreement with the observations which show distinct thin layers of ice particles with a maxima in $f_{\mathrm{BSR}}$ at the same height. BOLAM overstimates $f_{i}$ with respect to $f_{\mathrm{BSR}}$ and $75 \%$ of model ice clouds are of recent convective origin in the lower layer (estimated as the ratio between $f_{i c}$ and $f_{i}$ throughout the vertical range) whilst the fraction is around $30 \%$ in the upper layer. Within the $355-370 \mathrm{~K}$ layer, $f_{\mathrm{CO}_{2}}$ is large (up to $90 \%$ ) and corresponds to regions where low $\mathrm{CO}_{2}$ was observed (see Fig. 3) .

The analysis shows that local convection hydrates the upper troposphere over West Africa and, in one case (11 August), there is a significant impact up to $375 \mathrm{~K}$. Convection can induce an upward transport of water vapour and ice particles which can evaporate. This recent convection is superimposed on older convection which took place up to 3 days before the observations. Even if a detailed analysis of cirrus formation mechanisms is outside the scope of this paper, it is worth noting that modelled and observed layers of ice particles are in good agreement.

Ice particles appear to be formed directly in the main outflow below $360 \mathrm{~K}$ and their presence is correlated to the uplift seen by model. Above the main outflow, BOLAM humidity indicates that ice clouds often form in the TTL at the top of mesoscale convective systems. These results are in qualitative agreement with a recent analysis of CALIPSO and CLOUDSAT observations which concluded that TTL cirrus are likely observed close to deep convective clouds (Sassen et al., 2009).

\section{Conclusions}

The analysis presented here aimed to characterize the impact of deep convection on the West African upper troposphere in August 2006 using a combination of aircraft data and mesoscale modelling. In particular, three M55 flights were analysed where there was a clear presence of organized convective systems either close to the flights or upwind over eastern and central Africa up to 3 days earlier.

The observations of trace gases and aerosols collected during these flights on 7, 8 and 11 August, showed that it is possibile to identify a main convective outflow characterized by substantial hydration, low concentrations of $\mathrm{CO}_{2}$ and freshly nucleated ice particles. Deep convection largely determined the chemical composition up to a potential temperature level ranging between $355 \mathrm{~K}$ to $360 \mathrm{~K}$ that is assumed to be the top of the main outflow. These results confirm the results presented in Law2010 based on estimations using trajectories 
calculated from large-scale meteorological analyses. Moreover, convective signatures are often observed above the top of the main outflow up to the thermal tropopause ( $375 \mathrm{~K}$ ) and can be identified by observations of thin ice cloud layers, enhanced fine particles concentration and $\mathrm{CO}_{2}$ depletion. In particular, one specific event (11 August) clearly shows that the distributions of $\mathrm{CO}_{2}$ and fine particles were strongly perturbed up to the tropical tropopause. On the other hand, large perturbations in ozone are not always observed since this region is characterized by land based convection that transports air masses containing different levels of ozone and its precursors or aerosols (local pollution, biomass burning, soil $\mathrm{NO}_{\mathrm{x}}$, lightning $\mathrm{NO}_{\mathrm{x}}$ ). As discussed further in Law2010, largescale easterly transport in the TTL can also bring lightning $\mathrm{NO}_{\mathrm{x}}$ and pollutants from the Asian continent and air masses with marine convective signatures such as low $\mathrm{O}_{3}$ into the UT over West Africa and its superposition on different continental sources makes it difficult to use ozone as a tracer of deep convective transport in this region. This is clearly visible for instance during one event (8 August) where ozone is highly variable in the region of main convective outflow correlated to the latitudinal dependence of local sources.

Nudged mesoscale simulations performed with the BOLAM model correctly reproduce the general pattern of convection observed during the first 15 days of August 2006 and therefore, can be used to estimate the convective outflow and compared with the measurements. Passive boundary layer tracers are used to estimate the convective age, identify when uplift occurred and calculate the fraction of convectively uplifted air masses in the flight area.

BOLAM shows good agreement with convective perturbations derived from observations of aerosol and chemical tracers for the main convective outflow region below $355 \mathrm{~K}$ and indicates that West Africa convection influences around 30\% of air masses resulting in substantial hydration and formation of ice particles up to this level. Model tracers also indicate that convective outflow can be highly spatially variable and this might help to explain, at least on qualitative basis, the large variability in trace species observed by M55, for example, $\mathrm{O}_{3}$ on the 8 August event. BOLAM also correctly reproduces the outflow of a recent MSC on 11 August and simulates a large convective influence (up to 20\%) between $355-370 \mathrm{~K}$ in acceptable agreement with the convective fraction estimated from observations of $\mathrm{CO}_{2}$ and of freshly nucleated small particles.

Recent uplift (less than $24 \mathrm{~h}$ ) is mainly confined in the main convective layer while older uplift is important above $355 \mathrm{~K}$ showing that deep convection in the central Sahel has a non negligible role, at least with respect to the formation of ice layers. The event of deep convection on 11 August is characterized by air masses uplifted by recent convection up to the tropopause level; this is superposed to an older uplift, being responsible of the presence of thin ice clouds. This is confirmed, at least on qualitative basis, by in-situ observations of $\mathrm{CO}_{2}$, water vapor and aerosol that show the presence, in the upper troposphere, of perturbed trace gas concentrations, hydrated air and particles. Air masses perturbed by more recent convection are likely characterized by depleted $\mathrm{CO}_{2}$ and large concentrations of freshly nucleated particles whilst ozone shows concentrations slightly higher than in the mean convective outflow.

In-situ observations and model data helped to identify and quantify the role of deep convection in the TTL showing that local convection generates a main outflow that was sampled during the measurement campaign. The impact on atmospheric composition between the main outflow and the tropopause is more difficult to assess due to different sources and the role of large-scale westward transport. Nevertheless, it is possible to identify a clear signature of local convection in the observations. Model aided analysis confirms the presence of direct injection up to the tropical tropopause by intense convective systems and indicates that composition is dependent on the residence time in the TTL after convective uplift. An interesting extension of this work would be to implement the same analysis considering the whole monsoon season in order to characterize on the longer term (and larger scale) the impact of central/west African convection on the UT. Climatological analysis of METEOSAT data (Laing et al., 2008) shows Sahelian cold clouds often formed over Nigeria, Chad and Sudan, and possibly fed by trace species from biomass burning sources (Mari et al., 2008; Real et al., 2010). Extensive regional model simulations coupled with satellite data analysis would be necessary to quantify their impact on upper tropospheric composition.

Acknowledgements. The authors acknowledge the partial support of the EC SCOUT-O3 Integrated Project (505390- GOCE-CT2004). This work was partly supported by AMMA project. Based on French initiative, AMMA was built by an international scientific group and is currently funded by a large number of agencies, especially from France, UK, US and Africa. It has been the beneficiary of a major financial contribution from the European Community's Sixth Framework Research Programme. We acknowledge the anonymous reviewers for their valuable suggestions.

Edited by: C. Reeves

\section{References}

Adriani, A., Viterbini, M., Cairo, F., Mandolini, S., and Di Donfrancesco, G.:Multiwavelength Aerosol Scatterometer for airborne experiments to study the stratospheric particle optical properties: J. Atmos. Ocean. Technol., 16, 1328-1335, 1999.

Ancellet, G., Leclair de Bellevue, J., Mari, C., Nedelec, P., Kukui, A., Borbon, A., and Perros, P.: Effects of regional-scale and convective transports on tropospheric ozone chemistry revealed by aircraft observations during the wet season of the AMMA campaign, Atmos. Chem. Phys., 9, 383-411, doi:10.5194/acp-9-3832009, 2009.

Barret, B., Ricaud, P., Mari, C., Attiz, J.-L., Bousserez, N., Josse, B., Le Flochmon, E., Livesey, N. J., Massart, S., Peuch, V.- 
H., Piacentini, A., Sauvage, B., Thouret, V., and Cammas, J.P.: Transport pathways of $\mathrm{CO}$ in the African upper troposphere during the monsoon season: a study based upon the assimilation of spaceborne observations, Atmos. Chem. Phys., 8, 3231-3246, doi:10.5194/acp-8-3231-2008, 2008.

Bertram, T. H., Perring, A. E., Wooldridge, P. J., Crounse, J. D., Kwan, A. J., Wennberg, P. O., Scheuer, E., Dibb, J., Avery, M., Sachse, G., Vay, S. A., Crawford, J. H., McNaughton, C. S., Clarke, A., Pickering, K. E., Fuelberg, H., Huey, G., Blake, D. R., Singh, H. B., Hall, S. R., Shetter, R. E., Fried, A., Heikes, B. G., and Cohen, R. C.: Direct Measurements of the Convective Recycling of the Upper Troposphere, Science, 315, 816820, 2007.

Borrmann, S., Kunkel, D., Weigel, R., Minikin, A., Deshler, T., Wilson, J. C., Curtius, J., Volk, C. M., Homan, C. D., Ulanovsky, A., Ravegnani, F., Viciani, S., Shur, G. N., Belyaev, G. V., Law, K. S., and Cairo, F.: Aerosols in the tropical and subtropical UT/LS: in-situ measurements of submicron particle abundance and volatility, Atmos. Chem. Phys., 10, 5573-5592, doi:10.5194/acp-10-5573-2010, 2010.

Buzzi A. and Foschini, L.: Mesoscale meteorological features associated with heavy precipitation in the southern Alpine region. Meteorol. Atmos. Phys., 72, 131-146, 2000.

Cairo F., Di Donfrancesco, G., Adriani, A., Pulvirenti, L., and Fierli, F.: Comparison of Various Linear Depolarization Parameters Measured by Lidar Applied Optics, 38, 21, 4425-4432, 1999.

Cairo, F., Pommereau, J. P., Law, K. S., Schlager, H., Garnier, A., Fierli, F., Ern, M., Streibel, M., Arabas, S., Borrmann, S., Berthelier, J. J., Blom, C., Christensen, T., D’Amato, F., Di Donfrancesco, G., Deshler, T., Diedhiou, A., Durry, G., Engelsen, O., Goutail, F., Harris, N. R. P., Kerstel, E. R. T., Khaykin, S., Konopka, P., Kylling, A., Larsen, N., Lebel, T., Liu, X., MacKenzie, A. R., Nielsen, J., Oulanowski, A., Parker, D. J., Pelon, J., Polcher, J., Pyle, J. A., Ravegnani, F., Rivire, E. D., Robinson, A. D., Rckmann, T., Schiller, C., Simes, F., Stefanutti, L., Stroh, F., Some, L., Siegmund, P., Sitnikov, N., Vernier, J. P., Volk, C. M., Voigt, C., von Hobe, M., Viciani, S., and Yushkov, V.: An introduction to the SCOUT-AMMA stratospheric aircraft, balloons and sondes campaign in West Africa, August 2006: rationale and roadmap, Atmos. Chem. Phys., 10, 2237-2256, doi:10.5194/acp10-2237-2010, 2010.

Corti, T., Luo, B. P., Fu, Q., Vsmel, H., and Peter, T.: The impact of cirrus clouds on tropical troposphere-to-stratosphere transport, Atmos. Chem. Phys., 6, 2539-2547, doi:10.5194/acp-6-25392006, 2006.

Corti, T., Luo, B. P., de Reus, M., Brunner, D., Cairo, F., Mahoney, M. J., Martucci, G., Matthey, R., Mitev, V., dos Santos,F. H., Schiller, C., Shur, G., Sitnikov, N. M., Spelten, N., Vossing, H. J., Borrmann, S., and Peter, T.: Unprecedented evidence for deep convection hydrating the tropical stratosphere, Geophys. Res. Lett., 35, L10810, doi:10.1029/2008GL033641, 2008.

Chaboureau, J.-P., Cammas, J.-P., Duron, J., Mascart, P. J., Sitnikov, N. M., and Voessing, H.-J.: A numerical study of tropical crosstropopause transport by convective overshoots, Atmos. Chem. Phys., 7, 1731-1740, doi:10.5194/acp-7-1731-2007, 2007.

Curtius J.: Nucleation of atmospheric particles, C. R. Physique, 7, 1027-1045, 2006.

Dessler, A. E.: The effect of deep, tropical convection on the tropical tropopause layer, J. Geophys. Res., 107(D3), 4033, doi:10.1029/2001JD000511, 2002.

Drofa, O. V.: The parameterization of microphysical processes for atmospherical numerical models, Il Nuovo CImento, 26C(3), 233-262, 2003.

Fierli, F., Di Donfrancesco, G., Cairo, F., Marcal, V., Zampieri, M., Orlandi, E., and Durry, G.: Variability of cirrus clouds in a convective outflow during the Hibiscus campaign, Atmos. Chem. Phys., 8, 4547-4558, doi:10.5194/acp-8-4547-2008, 2008.

Folkins, I., Braun, C., Thompson, A. M., and Witte, J.: Tropical ozone as an indicator of deep convection, J. Geophys. Res. Atmos., 107(D13), 4184, doi:10.1029/2001JD001178, 2002.

Folkins, I. and Martin, R. V.: The vertical structure of tropical convection and its impact on the budgets of water vapor and ozone, J. Atmos. Sci.,62, 1560-1573, 2005.

Fueglistaler, S. and Fu, Q.: Impact of clouds on radiative heating rates in the tropical lower stratosphere, J. Geophys. Res., 111, D23202, doi:10.1029/2006JD007273, 2006.

Fueglistaler, S., Dessler, A. E., Dunkerton, T. J., Folkins, I., Fu, Q., and Mote, P. W.:, Tropical tropopause layer, Rev. Geophys., 47, RG1004, doi:10.1029/2008RG000267, 2009.

Gheusi, F. and Stein, J.: Lagrangian description of airflows using Eulerian passive tracers, Q. J. Roy. Meteorol. Soc., 128(579), 337-360, 2002.

Homan, C. D., Volk, C. M., Kuhn, A. C., Werner, A., Baehr, J., Viciani, S., Ulanovski, A., and Ravegnani, F.: Tracer measurements in the tropical tropopause layer during the AMMA/SCOUTO3 aircraft campaign, Atmos. Chem. Phys., 10, 3615-3627, doi:10.5194/acp-10-3615-2010, 2010.

Janicot, S., Thorncroft, C. D., Ali, A., Asencio, N., Berry, G., Bock, O., Bourles, B., Caniaux, G., Chauvin, F., Deme, A., Kergoat, L., Lafore, J.-P., Lavaysse, C., Lebel, T., Marticorena, B., Mounier, F., Nedelec, P., Redelsperger, J.-L., Ravegnani, F., Reeves, C. E., Roca, R., de Rosnay, P., Schlager, H., Sultan, B., Tomasini, M., Ulanovsky, A., and ACMAD forecasters team: Large-scale overview of the summer monsoon over West Africa during the AMMA field experiment in 2006, Ann. Geophys., 26, 25692595, doi:10.5194/angeo-26-2569-2008, 2008.

Kain, J. S.: The Kain-Fritsch convective parametrization: an update. J. App. Meteorol., 43, 170-181, 2004.

Khaykin, S., Pommereau, J.-P., Korshunov, L., Yushkov, V., Nielsen, J., Larsen, N., Christensen, T., Garnier, A., Lukyanov, A., and Williams, E.: Hydration of the lower stratosphere by ice crystal geysers over land convective systems, Atmos. Chem. Phys., 9, 2275-2287, doi:10.5194/acp-9-2275-2009, 2009.

Laing, A.G., Carbone, R., Levizzani, V., and Tuttle, J.: The propagation and diurnal cycles of deep convection in northern tropical Africa, Q. J. Roy. Meteorol. Soc., 134, 93-109, doi:10002/qj.194, 2008.

Law, K. S., Fierli, F., Cairo, F., Schlager, H., Borrmann, S., Streibel, M., Real, E., Kunkel, D., Schiller, C., Ravegnani, F., Ulanovsky, A., d'Amato, F., Viciani, S., and Volk, C. M.: Air mass origins influencing TTL chemical composition over West Africa during 2006 summer monsoon, Atmos. Chem. Phys., 10, 10753-10770, doi:10.5194/acp-10-10753-2010, 2010.

Mace, G. G., Benson, S., and Vernon, E.: Cirrus Clouds and the Large-Scale Atmospheric State: Relationships Revealed by Six Years of Ground-Based Data, J. Climate, 19, 3257-3278, doi:10.1175/JCLI3786.1, 2006. 
Mari, C. H., Cailley, G., Corre, L., Saunois, M., Atti, J. L., Thouret, V., and Stohl, A.: Tracing biomass burning plumes from the Southern Hemisphere during the AMMA 2006 wet season experiment, Atmos. Chem. Phys., 8, 3951-3961, doi:10.5194/acp8-3951-2008, 2008.

Marti, L. and Mauersberger, K.: A survey and new measurements of ice vapor pressure at temperatures between 170 and 250 K,Geophys. Res. Lett., 20, 363-366, 1993.

Morcrette, J. J., Clough, S. A., Mlawer, E. J., and Iacono, M. J.: Impact of a validated radiative transfer scheme, RRTM, on the ECMWF model climate and 10-day forecasts. ECMWF Technical Memo., 252, 1998

Mullendore G. L., Durran D. R., and Holton, J. R.: Cross.tropopause tracer transport in midlatitude convection, J. Geophys. Res., 116, D06113, doi:10.129/2004JD005059, 2005.

Orlandi, E., Fierli. F., Davolio, S., Buzzi, A., and Drofa, O.: A nudging scheme to assimilate satellite brightness temperature in a meteorological model: Impact on representation of African mesoscale convective systems, Q. J. Roy. Meteorol. Soc., 136(647), 462-474, 2010

Pfister, L., Selkirk, H. B., Jensen, E. J., Schoeberl, M. R., Toon, O. B., Browell, E. V., Grant, W. B., Gary, B., Mahoney, M. J., Bui, T. V., and Hintsa, E.: Aircraft observations of thin cirrus clouds near the tropical tropopause, J. Geophys. Res., 106(D9), 9765-9786, 2001.

Real, E., Orlandi, E., Law, K. S., Fierli, F., Josset, D., Cairo, F., Schlager, H., Borrmann, S., Kunkel, D., Volk, C. M., McQuaid, J. B., Stewart, D. J., Lee, J., Lewis, A. C., Hopkins, J. R., Ravegnani, F., Ulanovski, A., and Liousse, C.: Cross-hemispheric transport of central African biomass burning pollutants: implications for downwind ozone production, Atmos. Chem. Phys., 10, 3027-3046, doi:10.5194/acp-10-3027-2010, 2010.

Redelsperger, J. L., Thorncroft, C., Diedhiou, A., Lebel, T., Parker, D. J., and Polcher, J.: African Monsoon Multidisciplinary Analysis (AMMA): An International Research Project and Field Campaign, BAMS, 87(12), 1739-1746, 2006.

Reeves, C. E., Formenti, P., Afif, C., Ancellet, G., Attiz, J.-L., Bechara, J., Borbon, A., Cairo, F., Coe, H., Crumeyrolle, S., Fierli, F., Flamant, C., Gomes, L., Hamburger, T., Jambert, C., Law, K. S., Mari, C., Jones, R. L., Matsuki, A., Mead, M. I., Methven, J., Mills, G. P., Minikin, A., Murphy, J. G., Nielsen, J. K., Oram, D. E., Parker, D. J., Richter, A., Schlager, H., Schwarzenboeck, A., and Thouret, V.: Chemical and aerosol characterisation of the troposphere over West Africa during the monsoon period as part of AMMA, Atmos. Chem. Phys., 10, 7575-7601, doi:10.5194/acp-10-7575-2010, 2010.

Ritter, B. and Geleyn, J.: A comprehensive radiation scheme for numerical weather prediction models with potential applications in climate simulations, Mon. Weather Rev., 120, 303-325, 1992.

Rivière, E. D., Marecal, V., Larsen, N., and Cautenet, S.: Modelling study of the impact of deep convection on the UTLS air composition. Part 2: budget of ozone in the TTL, Atmos. Chem. Phys., 6, 1585-1598, doi:10.5194/acp-6-1585-2006, 2006.
Sassen K., Wang, Z. and Liu, D. , Cirrus clouds and deep convection in the tropics: Insights from CALIPSO end CloudSat, Journ. Geophys. Res., 114, D00H06, doi:10.129/2009JD011916, 2009.

Saunders, R. and Brunel, P.: RTTOV 8.5 user guide, EUMETSAT SAFNWP http://www.metoffice.gv.uk/research/interproj/ nwpsaf/rtm/, 2004.

Saunois, M., Reeves, C. E., Mari, C. H., Murphy, J. G., Stewart, D. J., Mills, G. P., Oram, D. E., and Purvis, R. M.: Factors controlling the distribution of ozone in the West African lower troposphere during the AMMA (African Monsoon Multidisciplinary Analysis) wet season campaign, Atmos. Chem. Phys., 9, 61356155, doi:10.5194/acp-9-6135-2009, 2009.

Schultz, P.: An explicit cloud physics parameterization for operational numerical weather prediction, Mon. Weather Rev, 123, 3331-3343, 1995.

Schmetz J., Tjemkes, S. A., Gube, M., and van de Berg, L.: Monitoring deep convection and convective overshooting with METEOSAT, Advances in Space Research, Proceedings of the A0.1 Symposium of COSPAR Scientific Commission A, 19(3), 433441, 1997.

Schiller, C., Grooß, J.-U., Konopka, P., Plöger, F., Silva dos Santos, F. H., and Spelten, N.: Hydration and dehydration at the tropical tropopause, Atmos. Chem. Phys., 9, 9647-9660, doi:10.5194/acp-9-9647-2009, 2009.

Schumann, U. and Huntrieser, H.: The global lightning-induced nitrogen oxides source, Atmos. Chem. Phys., 7, 3823-3907, doi:10.5194/acp-7-3823-2007, 2007.

Stewart, D. J., Taylor, C. M., Reeves, C. E., and McQuaid, J. B.: Biogenic nitrogen oxide emissions from soils: impact on $\mathrm{NO}_{\mathrm{x}}$ and ozone over west Africa during AMMA (African Monsoon Multidisciplinary Analysis): observational study, Atmos. Chem. Phys., 8, 2285-2297, doi:10.5194/acp-8-2285-2008, 2008.

Viciani, S., D’Amato, F., Mazzinghi, P., Castagnoli, F., Toci, G., and Werle, P.: A cryogenically operated laser diode spectrometer for airborne measurement of stratospheric trace gases, Appl. Phys. B, 90, 581-592, 2008.

Voigt, C., Schlager, H., Roiger, A., Stenke, A., de Reus, M., Borrmann, S., Jensen, E., Schiller, C., Konopka, P., and Sitnikov, N.: Detection of reactive nitrogen containing particles in the tropopause region evidence for a tropical nitric acid trihydrate (NAT) belt, Atmos. Chem. Phys., 8, 7421-7430, doi:10.5194/acp-8-7421-2008, 2008.

Volk, C. M., Riediger, O., Strunk, M., Schmidt, U., Ravegnani, F., Ulanovsky, A., and Rudakov, V.: In situ Tracer Measurements in the Tropical Tropopause Region During APE-THESEO, Eur. Comm. Air Pollut. Res. Report 73, 661-664, 2000.

Yushkov, V., Ouloanovsky, A., Lechenuk, N., Roudakov, I., Arshinov, K., Tikhonov, F.,Stefanutti, L., Ravegnani, F., Bonaf, U., and Georgiadis, T.: A chemiluminescent analyzer for stratospheric measurements of ozone concentration (FOZAN), J. Atmos. Ocean. Tech., 16, 1345-1350, 1999. 